\title{
The High Court of Australia at Mid-Century: Concealed Frustrations, Private Advocacy, and the Break with English Law
}

\author{
TANYA JOSEV
}

The 1940s were unhappy years for the High Court of Australia, not least because of the early impact of the World War on the Court's members and their families. ${ }^{1}$ The decade was driven by disunity. Personal relations between certain judges were at a low ebb; ${ }^{2}$ the Court had to endure lengthy periods with depleted numbers as judges were called to wartime diplomatic duties; ${ }^{3}$ and the majority's repeated stymying of the Labor government's postwar reconstruction programme caused deep divisions both internally and externally. ${ }^{4}$ Yet the 1940 s also represented a time in which the Court, at least publicly, offered an almost unanimous view on the importance of English law to the Australian jurisdiction. This view had not arisen as a response to wartime insecurity. Rather, the Court seemed to be making a more general appeal for collaboration between the English and Australian judiciaries. ${ }^{5}$ But the Court's views in this period have also been taken by select judges and historians as reflective of a

${ }^{1}$ Chief Justice Latham, for instance, lost his eldest son in overseas military service in 1943. An introductory statement should be made as to the use of the term 'Common law' in this chapter. The term is used loosely here for the sake of coherency: that is, to encompass equitable principle as well as Common law principle, consistent with the use of the term in the various judgments and extra-judicial speeches quoted within.

2 Justice Dixon, for instance, found himself at odds with Latham's approach; Justice Starke, who had a history of falling out with his fellow judges, was particularly critical of Justice McTiernan during this decade.

${ }^{3}$ Chief Justice Latham, for instance, spent time as Australia's minister (ambassador) to Japan; Justice Dixon was asked to take leave to become minister to Washington; Justice Webb acted on postwar international tribunals.

${ }^{4}$ See, e.g. Attorney-General (Vic) v. Commonwealth (1945) 71 CLR 237; Bank of New South Wales v. Commonwealth (1948) 76 CLR 1 ('Bank Nationalisation case'); British Medical Association v. Commonwealth (1949) 79 CLR 201.

5 See, e.g. Waghorn v. Waghorn (1942) 65 CLR 289; Piro v. Foster (1943) 68 CLR 313; Wright v. Wright (1948) 77 CLR 191. 
wholesale deference towards the English courts for the first half of the twentieth century, only punctuated later by outlier cases such as Parker v. The Queen (1963). ${ }^{6}$ Under this view, the High Court gained increasing autonomy from 1968 onwards, when various legislative efforts eventually dismantled all avenues of appeal from Australian courts to the Privy Council. ${ }^{7}$

This traditional account of the evolution of Australian judicial independence' warrants further study - particularly the circumstances surrounding the delivery of the High Court's judgment in Parker insofar as it represented an explicit break from following House of Lords precedent. Parker is all the more interesting because the author of its most celebrated passages, Chief Justice Dixon, was also one of the judges supportive of a unified Common law in the 1940s - even when unity came at the expense of following the High Court's own precedent. Parker has been variously described as an early, 'fatal crack' in the relationship between the Australian and English courts; ${ }^{8}$ as a 'decisive landmark' in the evolution of a distinct Australian law;' and even as a 'Declaration of Judicial Independence'. ${ }^{10}$ But Parker, landmark or not, is often characterised as a singular event, an aberration in a wider, enduring story of the Australian judiciary's long-standing, 'internalised imperialism'11 and subservience to the superior courts of England. ${ }^{12}$ It is only in more recent

6 (1963) 111 CLR 610 ('Parker').

7 See, for example, the essays reflecting on the state of the law at the time of the Australian bicentenary in M. Ellinghaus, A. Bradbrook and A. Duggan (eds.), The Emergence of Australian Law (Oxford, 1989); B. Kercher, An Unruly Child: A History of Law in Australia (Crows Nest, 1995), 188; A. Mason, 'Future Directions in Australian Law', Monash University Law Review, 13 (1987), 149-63; M. Gleeson, 'The Privy Council: An Australian Perspective', speech delivered to the Anglo-Australian Lawyers' Society, The Commercial Bar Association and The Chancery Bar Association, London (18 June 2008), 24, available at www.hcourt.gov.au/assets/publications/speeches/former-justices/glee soncj/cj_18jun08.pdf.

${ }^{8}$ Kercher, An Unruly Child, 177.

9 T. Blackshield, 'Parker v The Queen', in T. Blackshield, M. Coper and G. Williams (eds.), The Oxford Companion to the High Court of Australia (Oxford, 2001), 523.

${ }^{10}$ M. Kirby, 'The Old Commonwealth - Australia and New Zealand', in L. Blom-Cooper, B. Dickson and G. Drewry (eds.), The Judicial House of Lords 1876-2009 (Oxford, 2009), $339-50$, at 341 .

${ }^{11}$ Kercher, An Unruly Child, 166.

12 See, for instance, former Chief Justice of the High Court Murray Gleeson's observation that 'the early Australian attitude' towards appeals to the Privy Council in civil and criminal cases was positive: 'Australians recognised and greatly valued the legal capacity of the senior United Kingdom judges. They expected it would continue to be available to them'; Gleeson, 'The Privy Council: An Australian Perspective', 8. Gleeson later added that there was no comparable 'intensity of feeling' about the constitutional role of the 
years that scholarship has emerged that suggests that the development of a distinct Australian Common law was evident in the early years following Federation. Early law reports reveal that even trial judges were prepared to diverge from English precedent where circumstances compelled it in private law cases; although it must be conceded that these judgments were usually expressed in a subtle, politic manner, far removed from the forthright prose of Parker. ${ }^{13}$

Parker was handed down less than a year before Dixon's retirement from the Court. ${ }^{14}$ Dixon sought the approval of the other members of the Court before making his 'declaration' in his dissenting judgment; every other member of the Court willingly authorised him to make the remarks on their behalf. The Court had been invited to follow the precedent of the House of Lords in the criminal case of Director of Public Prosecutions v. Smith, ${ }^{15}$ that an accused should be presumed to intend the natural and probable consequences of their acts. Dixon wrote unapologetically:

Hitherto I have thought that we ought to follow decisions of the House of Lords, at the expense of our own opinions, but having carefully studied Smith's Case I think we cannot adhere to that view or policy. There are positions laid down in the judgment which I believe to be misconceived and wrong ... I wish there to be no misunderstanding on the subject. I shall not depart from the law on the matter as laid down in this Court and I think Smith's Case should not be used as authority in Australia at all. ${ }^{16}$

Parker can certainly be interpreted as a directive from the bench of a (domestic) apex court to the judges below that a degree of freedom had been granted to consider prevailing local conditions in developing the Common law, rather than to slavishly observe English precedent. But within the Court, the decision to make such a directive in such an extraordinary manner was not taken lightly. Rather, the decision

Privy Council in Australia as there was, say, in Canada in the mid-twentieth century; at 11 .

${ }^{13}$ It is not possible to provide an exhaustive list of this work in this volume, but for the most recent examples, see, e.g. the work of Mark Lunney with respect to the development of an Australian law of tort: M. Lunney, A History of Australian Tort Law 1901-1945: England's Obedient Servant? (Cambridge, 2018). See also A. Loughnan, Self, Others and the State (Cambridge, 2019), esp. ch 4 ('The "Birth" of Australian Criminal Law'), and M. Finnane, 'Irresistible Impulse: Historicising a Judicial Innovation in Australian Insanity Jurisprudence', History of Psychiatry, 23 (2012), 454-68.

14 Parker v. The Queen (1963) 111 CLR 610.

15 Director of Public Prosecutions v. Smith [1961] AC 290 ('Smith').

16 Parker v. The Queen (1963) 111 CLR 610, 632. 
reflected years of internal anguish about the 'Privy Council situation' in particular. Thus, the bench was not suddenly emboldened; the sentiments contained in Parker did not reflect grievances only freshly suffered. This essay attempts to tease out some of the private concerns of the judges of the High Court in the years leading up to the decision in Parker, and to provide some context for what is otherwise arguably perceived of as the most sensational judicial volte-face in Australian legal history. It tentatively concludes that, regardless of the Court's public avowals of adherence to English legal principle, there existed longrunning tensions and failed attempts at private advocacy before the reluctant decision was taken to jettison aspirations of a unified Common law. To this end, the traditional account of an emerging Australian jurisprudence is affirmed: Parker does reflect a break with English ties, even if provoked not by a fervent sense of 'nationalism' but by growing concern at developments in the English Common law and the operations of the Privy Council. But Parker is by no means an anomaly: it is the inevitable endpoint of a judicial relationship that had been in decline for at least two decades.

Before proceeding further, a word of caution should be expressed about the primary sources used in this essay. The personal papers of High Court judges are not readily available in Australian repositories; the hesitancy of judges to leave their papers for future scholars has only been addressed by the National Archives recently (the institution now aims to encourage retiring judges to leave their papers in Canberra upon retirement). ${ }^{17}$ To this end, much reliance is placed here on the public extrajudicial writing of the judges, as well as the singular (and rich) archive of Sir Owen Dixon. Dixon's papers were placed in the National Library in 2010 (Dixon died in 1972). ${ }^{18}$ It is Dixon's account of his dealings with fellow judges and politicians in the years leading up to Parker that forms the primary narrative in this chapter.

${ }^{17}$ National Archives of Australia, 'Records Authority 2010/00663993 - High Court of Australia' (Records Authority, 22 November 2010), [9]. This provision was inserted into the Authority in 2010. See generally T. Josev, 'Judicial Biography in Australia: Obstacles and Opportunities', University of New South Wales Law Journal, 40 (2017), 842-61.

18 O. Dixon, Papers of Sir Owen Dixon, in National Library of Australia (henceforth 'NLA'), MS Acc.09. The papers are not yet processed. The references that follow in this chapter therefore use box numbers, followed by the informal annotations made on the corner of each document (believed to have been made either by Dixon's former associate, the late Jim Merralls QC, or Dixon's biographer, Philip Ayres). 


\section{A Unified Common Law: At What Cost?}

The High Court personnel at mid-century were held in high regard internationally. Dixon, in particular, was viewed even beyond Australia as the preeminent antipodean jurist of his generation, with justices Windeyer and the late Fullagar following closely behind. Dixon's overseas diplomatic missions in the 1940s enabled him to cultivate friendly relations with a wide network of jurists and statesmen, some of whom became his lifelong correspondents. These included United States Supreme Court Justice Felix Frankfurter and, in Britain, the eminent jurists Simonds, Pearce, Reid and Denning. ${ }^{19}$ These correspondents wrote to him privately, and at length, to express their admiration for his work, and to inform him of their reliance on his judgments in drafting their own. Dixon was no mere apostle of the classical, nineteenth-century, English approach of strict logic and high technique in developing the law (much as he admired the era): his brand of 'legalism' was particularly nuanced and acknowledged the incursions that legal realism was making into the study of law. ${ }^{20}$ Thus it is somewhat surprising to find that Dixon, and later Windeyer, became frustrated over time at what they perceived to be a routine ignorance of High Court jurisprudence in the English courts. ${ }^{21}$ The unity of the Common law, it seemed, flowed mainly in one direction: the High Court declared its commitment to working with English principles, but no corresponding assurance was consistently evident in the written judgments from London.

A careful examination of the three early cases in which the Court reaffirmed its commitment to English precedent bear this out. Despite these cases sometimes being taken as examples of judicial obsequiousness

${ }^{19}$ Viscount Simonds was, at the time of his correspondence with Dixon, a lord of appeal in ordinary and sat on the Privy Council. He was lord chancellor from 1951 to 1954 before returning to his previous judicial role. Baron Pearce was, at the time of his correspondence with Dixon, a lord justice of appeal and sat on the Privy Council. In 1962, he was made a lord of appeal in ordinary. Baron Reid was a lord of appeal in ordinary at the time of corresponding with Dixon. Baron Denning was, at the time of his correspondence with Dixon, a lord justice of appeal (appointed 1948) and later a lord of appeal in ordinary (from 1957) before being appointed master of the rolls in 1962.

20 M. Coper, 'Concern about Judicial Method', Melbourne University Law Review, 30 (2006), 554-75; K. Hayne, 'Sir Owen Dixon', in J. Gleeson, J. Watson and E. Peden (eds.), Historical Foundations of Australian Law, 2 vols. (Alexandria, 2011), vol. I, 372-407.

${ }^{21}$ See Dixon J's judgments in Waghorn v. Waghorn (1942) 65 CLR 289 and the discussion below in relation to Attorney-General (SA) v. Brown [1960] AC 432 and Director of Public Prosecutions v. Smith [1961] AC 290. 
towards England, another conclusion may be drawn. That conclusion is not that Dixon et al. had an enduring faith in the infallibility of English jurisprudence, but rather that the maintenance of the unified Common law was of paramount concern in Australian decision-making. This largely reflects a pragmatic view held not just by judges, but by some of the judges' political contemporaries at this time. (As shall be discussed, those political contemporaries were unyielding in this view, thus being of little support to the later Dixon Court as it sought to abandon its initial stance.)

In the first case, Waghorn v. Waghorn, decided in 1942, the High Court heard a matter which ultimately required a decision to be made about the application of directly analogous High Court precedent or English precedent: not Privy Council or House of Lords precedent, but English Court of Appeal precedent. The case, falling within the (then) fault-based matrimonial causes jurisdiction, explored whether the High Court might make a decree for the dissolution of a marriage on behalf of a husband on the basis of his wife's desertion. ${ }^{22}$ The husband had committed adultery; but the wife had not been aware of this particular betrayal when deciding to leave. The husband was now living with another woman. Three of the five judges indicated they would have preferred to adopt the High Court's own directly applicable precedent, which would have permitted them to reject a finding of 'wilful' desertion on the part of the wife. ${ }^{23}$ However, as puisne Justice Dixon noted, it appeared that in England the Court of Appeal had not had the benefit of reading the Australian precedent on point, and had subsequently decided an analogous case in favour of a husband. Dixon concluded that even though the majority judges were confident of the correctness of their previous decision, there were wider matters to consider. Without wishing to defer to the Court of Appeal on a wholesale basis, Dixon nevertheless suggested that at the very least, in cases involving general propositions, the High Court should be wary of embarking on 'needless divergences' from English law. ${ }^{24}$

22 Waghorn v. Waghorn (1942) 65 CLR 289. See also V. Windeyer, 'Unity, Disunity and Harmony in the Common Law', in B. Debelle (ed.), Victor Windeyer's Legacy: Legal and Military Papers (Alexandria, 2019), 114-28.

${ }^{23}$ Starke J, although agreeing with the majority that the wife's appeal should be allowed, thought the previous Australian authority on point was wrongly decided: Waghorn v. Waghorn (1942) 65 CLR 289, 294.

${ }^{24}$ Ibid., 297. 
A year later, with Dixon away from the Court on diplomatic duties, in Piro v. Foster the Court reaffirmed its position of deference to English law at the expense of direct High Court precedent, this time in relation to principles of contributory negligence established by the House of Lords. ${ }^{25}$ Chief Justice Latham observed that while the Court was not 'technically' bound by the decisions of the House of Lords, there were 'convincing reasons' to proceed as if the decisions were binding - namely, uniformity of principle across the Empire. ${ }^{26}$

In 1948, with Dixon having returned to the bench, he made his strongest statement yet about the necessity of following English precedent. In Wright v. Wright - yet another matrimonial causes matter - the Court considered the applicable standard of proof in adultery cases, noting that the Court had previously preferred the Briginshaw v. Briginshaw standard. ${ }^{27}$ Nevertheless, a recent Court of Appeal decision had adverted to a criminal standard of proof being required. Dixon observed that it would be

better that this Court should confirm to English decisions which we think have settled the general law ... than that we should be insistent on adhering to reasoning we believe to be right but will create diversity ... Diversity in the development of the common law ... seems to me to be an evil. Its avoidance is more desirable than a preservation here of what we regard as sounder principle. ${ }^{28}$

Dixon nevertheless went on to find that, given the high level of uncertainty across England in various aspects of matrimonial jurisprudence, he preferred to follow Australian precedent on this occasion. ${ }^{29}$

While all three cases expressed the need for a unified Common law in similar terms, Dixon's judgments are of particular interest. In Waghorn, Dixon reluctantly forgave the Court of Appeal for ignoring the High Court's precedent; in Wright, he forgave both the Court of Appeal and the House of Lords for widespread inconsistencies in principle across the matrimonial jurisdiction. Perhaps at this point he saw these difficulties as par for the course on the basis of the physical distance between the jurisdictions or, at the very least, on the basis that discrepancies of

${ }^{25}$ Piro v. Foster (1943) 68 CLR 313.

${ }^{26}$ Ibid., 320.

${ }^{27}$ Briginshaw v. Briginshaw (1938) 60 CLR 336. The 'Briginshaw principle' is the civil standard of proof (i.e., on the balance of probabilities).

${ }^{28}$ Wright v. Wright (1948) 77 CLR 191, 210 (Dixon J).

29 Ibid., 211. 
opinion were to be expected in any judicial hierarchy. Yet these rationalisations did not hold for Dixon or his colleagues as time went on.

By the 1950s, developments in other areas of law also frustrated the High Court judges. The first of these concerns did not relate to any specific disjuncture of Australian and English law, but rather to judicial personnel. Dixon had been following the renewed interest in promissory estoppel in the English courts, as first advanced by Lord Denning in the High Trees case of $1947 .{ }^{30}$ Dixon began to take an interest in Denning himself. Dixon questioned not only Denning's methodologies, but also his extra-judicial communications with the wider public. Dixon's relationship with Denning had begun on friendly footing: the judges became acquaintances by the early 1950s, and Denning wrote delightedly to Dixon to advise him that his reading of the Australian case law on estoppel indicated it was moving in the same direction as England. 'It would be very good if we could all advance on the same broad point and learn from each other', remarked Denning. ${ }^{31}$ Here, indeed, was an English judge willing to study developments from the Australian jurisdiction. But Dixon, who received updates on Denning's endeavours from his close friend Viscount Simonds, soon took a dim view of the man he began to regard as a 'deliberate innovator'. Denning and his followers, it seemed, would be willing to cut across the basic contract principles of offer, acceptance and consideration in favour of advancing the High Trees principles - that is, allowing a remedy in the case of a promise relied upon and later withdrawn, even if consideration was never furnished. ${ }^{32}$ Dixon's view of the law, and of the impropriety of judges speaking candidly about the indeterminacies of judicial law-making, could not have been further from Denning's position. Dixon thought a model judge ought to believe in a discernible set of external standards that could be applied in most situations; this positivistic faith in external law was essential to principled decision-making. Writing to another of his correspondents, Frankfurter, Dixon bemoaned Denning's repeated public

${ }^{30}$ Central Property Trust Ltd v. High Trees House Ltd [1947] KB 130. Dixon's estoppel jurisprudence can hardly be regarded as an impediment to the continued development of the area either: his decision on estoppel in pais in Grundt v. Great Boulder Pty Gold Mines $L t d$ (1937) 59 CLR 641 is still routinely referred to by judges seeking to extend the reach of equitable principles today: see, e.g. Sidhu v. Van Dyke (2014) 251 CLR 505 and ASPL v. Hills Industries Ltd (2014) 253 CLR 560.

31 Letter from T. Denning to O. Dixon, 15 July 1953, from NLA, MS Acc.09, Box 5, PP12.34.

32 O. Dixon, 'Concerning Judicial Method', Australian Law Journal, 29 (1956), 468-76, at 472 (emphasis added). 
statements that emphasised the creative aspect of the judicial function. 'He (Denning) ought to appear to believe that he has some external guidance, even if in his ignorance he regards it as untrue', Dixon remarked. ${ }^{33}$ Dixon seemed concerned that Denning would produce judicial acolytes who would bring the English courts into disrepute. In 1955 Dixon proudly told an American audience that there was no such evidence of judicial innovation on the High Court bench. ${ }^{34}$

The second concern, unsurprisingly, related to developments (or lack thereof) in criminal law, and certainly directly presaged the decision in Parker. The High Court had sought, since its decision in Stapleton in 1952, to distance itself from rigidly narrow English precedent on the interpretation of the M'Naghten rule on the defence of insanity (specifically, the rejection of evidence of 'irresistible impulse' as relevant to a defence of insanity). ${ }^{35}$ The Court in Stapleton had remarked that a rule whereby the criminally accused is presumed to intend the natural consequences of their acts was 'seldom helpful and always dangerous. ${ }^{36}$ Dixon took the opportunity in a public lecture to opine that the failure to expand the M'Naghten rule, or at least make some acknowledgement of medical developments in the understanding of mental illness, had rendered certain English cases a 'discreditable chapter of the law'. ${ }^{37}$ In 1959, the Privy Council overruled the High Court's Brown decision, in which an order of retrial had been made for a case in which the trial judge specifically informed the jury that 'uncontrollable impulse' was no defence to murder. ${ }^{38}$ No doubt this frustrated the members of the High Court, but the final straw appeared to occur in 1961 - not in an appeal of the Australian case, but in an English case itself. The House of Lords in Smith again affirmed the presumption that an accused intended the

${ }^{33}$ Letter from O. Dixon to F. Frankfurter, 14 January 1959, from NLA, MS Acc.09. Box 3. PP7.73.

${ }^{34}$ Dixon, 'Concerning Judicial Method', 472.

35 Stapleton v. The Queen (1952) 86 CLR 358, referring specifically to $R$ v. Windle [1952] 2 QB 82. Note too that Dixon had been particularly concerned since the 1930s with how courts might appreciate new medical understandings of insanity; see, e.g. $R$ v. Porter (1933) 55 CLR 182 and Sodeman v. The King (1936) 55 CLR 192 (which was taken on appeal, with the Privy Council rejecting Dixon's formulation). Dixon took a particular interest in medical understandings of insanity, and he was a member of the Medico-Legal Society of Victoria for some time.

36 Stapleton v. The Queen (1952) 86 CLR 358, 365 (Dixon CJ, Webb and Kitto JJ).

37 O. Dixon, 'A Legacy of Hadfield, M'Naghten and Maclean', Australian Law Journal, 31 (1957), 255-66, at 261.

38 Attorney-General (SA) v. Brown [1960] AC 432. 
natural consequences of their acts, the very presumption that the High Court had questioned the utility of nine years earlier in Stapleton. ${ }^{39}$ It appeared no headway had been made in developing this area of the law. One of Dixon's associates recalled Justice Fullagar entering Dixon's chambers upon hearing of the result, saying 'Well, Dixon, they're hanging men for manslaughter in England now'. ${ }^{40}$ In these circumstances, it seems not too controversial to surmise that the Court resolved to take the next opportunity that arose to decry the application of Smith in Australia. That opportunity arose two years later, in Parker.

Although this is by no means an exhaustive list of the Court's 'frustrations' over Common law developments in England at mid-century, it may suffice to provide a backdrop to some of the Court's more pragmatic concerns that probably further propelled Dixon towards making the statement in Parker. For, while the decision in Parker seemingly related only to the development of a unified Common law, it appears that matters quite separate to Common law principle also operated as motivating factors in the drafting of the judgment. These matters related primarily to the operation of the Privy Council.

\section{The Privy Council's Unwitting Role in Parker}

The Privy Council was the highest appellate court in Australia until 1986. While later-twentieth-century objections towards that court remaining at the apex of the Australian judicial system are well known - they relate just as much to nationalistic aspirations as to a growing confidence in the competency of the High Court being able to work independently of London - it is worth observing that objections to the Privy Council's role in Australian law have existed since well before Federation. Early sentiments were assuaged to some extent by the British Colonial Office's modest concession, during federation negotiations, towards the Privy Council having at best an irregular role in conducting judicial review (that is, permitting the High Court itself to decide whether to grant leave to appeal to the Privy Council on matters involving the limits inter se of the constitutional powers of the states and the Commonwealth under section 74 of the Constitution). Of course, this did not stop the first Chief Justice of the High Court, Samuel Griffith, stating in the 1907 case of Baxter v. Commissioners of Taxation that at the time of Federation 'the

39 Director of Public Prosecutions v. Smith [1961] AC 290.

40 P. Ayres, Owen Dixon (Melbourne, 2003), 276. 
eminent lawyers who constituted the Judicial Committee were not regarded either as being familiar with the history of conditions of the remoter part of the Empire, or having any sympathetic understanding of the aspirations of the younger communities which had long enjoyed the privilege of self-government, ${ }^{41}$

In practice, the Privy Council's interventions into constitutional matters were more regular than anticipated, and, according to various members of the Court, these interventions revealed little understanding of the practical complexities of the Australian constitutional arrangements. The Privy Council variously held that matters involving the interpretation of section 92 (freedom of interstate trade) and section 109 (inconsistency between state and federal laws) of the Constitution were not usually inter se matters, opening up a further avenue for disgruntled litigants to sidestep High Court precedent. It is the Privy Council's 'section 92 cases' that brought particular consternation in the late 1940s, reaching a crescendo by the time that Parker was handed down. As the entry on the Privy Council in the Oxford Companion to the High Court of Australia observes, 'the Privy Council never had a sufficient flow of Australian constitutional cases to develop a proper understanding of the Australian Constitution, but did have enough to do considerable damage. ${ }^{42}$ The Privy Council had already overruled the High Court's understanding of section 92 in James v. Cowan in 1932 and in James v. Commonwealth in $1936,{ }^{43}$ but the low point was the Bank Nationalisation case of 1947, in which the Privy Council acknowledged that while it did not have jurisdiction to hear the case (as it involved an inter se question), given the efforts of the parties to put their case in London, an opinion on the matter would nevertheless be proffered. ${ }^{44}$ Dixon was incensed, even if the advisory opinion endorsed his own views. He wrote to Frankfurter of the 'ingenious paradoxes' contained in the labyrinthine prose: 'I find myself quite at sea because I cannot

${ }^{41}$ Baxter v. Commissioners of Taxation (NSW) 4 CLR 1087, 1111-12.

42 T. Blackshield, M. Coper and J. Goldring, 'Privy Council', in Blackshield et al. (eds.), Oxford Companion to the High Court of Australia, 560-4, at 561 (quoting constitutional scholar Geoffrey Sawer).

43 James v. Cowan (1932) 47 CLR 386; [1932] AC 542; James v. Commonwealth (1936) 55 CLR 1; [1936] AC 578.

${ }^{44}$ Commonwealth Bank v. Bank of New South Wales [1950] AC 235. 
understand the reasons given for a view which was supposed to be mine. ${ }^{45}$ Several years later, in Hughes \& Vale v. New South Wales, the Privy Council ironically enough endorsed an approach Dixon had already abandoned on account of the directives given by the Privy Council in earlier section 92 judgments. ${ }^{46}$ Taken together, this series of cases appears to have pushed Dixon to commence the process of consensusbuilding in the Court to advocate collectively for Privy Council change, as will be discussed shortly.

Yet the Court's concerns about the Privy Council did not begin and end with its section 92 jurisprudence. The Privy Council's constituency and collective ability were also raised as a source of apprehension. For Chief Justice Latham (as he then was) and Justice Starke, some of the received case law was a source of puzzlement. ${ }^{47}$ For others, such as Justice Menzies and Dixon, the evidence indicated that the members of the board did not 'have a clue'. ${ }^{48}$ Windeyer and Fullagar were more temperate in their public remarks, but even Windeyer adverted to the possibility that the law lords were ignoring precedent from other Commonwealth jurisdictions in considering the matters before them. ${ }^{49}$

For Dixon, the problems of the Privy Council were an acute source of anguish. Dixon's attachment to Britain was particularly strong: he described his visits to London as akin to coming home. On Australian soil, this feeling presented itself as what we now regard as a particular narrow-mindedness. He was a supporter of the White Australia policy; he became overtly concerned at the 'Americanisation' of postwar society ${ }^{50}$ he was unsettled about immigration from the north. ${ }^{51} \mathrm{He}$ had spoken proudly of the fact that Australia was '97 per cent British', noting that the relationship between Britain and Australia was one of interdependence and mutual reliance. ${ }^{52}$ The disappointments emerging

${ }^{45}$ Letter from O. Dixon to F. Frankfurter, 30 October 1952, from NLA, MS Acc.09, Box 3, 63A.

${ }^{46}$ Hughes \& Vale Pty. Ltd. v. New South Wales (1954) 93 CLR 1.

47 See, e.g. Ayres, Owen Dixon, 80.

48 Ibid., 246.

49 Windeyer, 'Unity, Disunity and Harmony in the Common Law', 126.

${ }^{50}$ Letter from O. Dixon to E. Pearce, 10 December 1959, from NLA, MS Acc.09, Box 5, PP12.52.

${ }^{51}$ See, e.g. letter from O. Dixon to G. Simonds, [undated] 1953, from NLA, MS Acc.09, Box 3, PP7.60.

52 O. Dixon, 'An Address by Sir Owen Dixon, Australian Minister to Washington before the Tulane University of Louisiana, to be delivered on Thurs Feb 10 4pm', 10 February 1944, from NLA, MS Acc.09, Box 8, MISC3.84. 
from the Privy Council must have been particularly hard to bear given Dixon's cultural loyalties. Thus two developments in particular gave Dixon pause for thought in the years leading up to the decision in Parker. The first was the news that discussions were afoot to staff the Judicial Committee with several Dominion representatives: Dixon worried that Africans might be appointed to oversee appeals from the High Court. The second was the news that the Judicial Committee might begin hearing appeals in the Dominions, which was further cause for alarm. His objection was not on nationalistic grounds, but rather that it afforded smaller jurisdictions little of the autonomy supposedly championed by Britain. 'For a body to come from London to Australia and superintend the administration of justice here would be much resented and I think rightly so', Dixon wrote to Pearce in 1959. 'It completely loses the sight of the position in Australia. ${ }^{53}$ Adding to Dixon's growing resentment of the Privy Council was the fact that this news had not been conveyed to him personally (he had been appointed to the Privy Council some years earlier, though he never sat on a case). He heard of the potential reforms on the wireless. ${ }^{54}$

To some extent, this Anglophilic sentiment explains why Dixon and indeed other members of the Court bore their disappointments privately during the course of most of the 1940s and 1950s. Even after the decision in Parker was handed down, other judges were keen to maintain a respectful deference towards the English judiciary in extra-legal communication, if not in their judgments. Whether this was done as a self-protective measure or as a genuine expression of fidelity to a single Common law is not known. Note, for instance, Justice Menzies' impassioned defence of a unified law in 1968. In 1954, he had privately expressed his dismay at section 92 jurisprudence in a lengthy conversation with Dixon. In 1963, he consented to Dixon making the wellknown remarks in Parker on his behalf. By 1968, however, he suggested that he ultimately supported the Privy Council's section 92 jurisprudence, and that it reflected prevailing legal opinion. Not only that, but Menzies was saddened by the divergence of the Common law between the jurisdictions:

${ }^{53}$ Letter from O. Dixon to E. Pearce, 30 December 1959, from NLA, MS Acc.09, Box 5, PP12.54.

${ }^{54}$ Ibid. Dixon was appointed to the Privy Council in 1951. 
The decisions of the House of Lords, the High Court and the Privy Council together have had the unfortunate consequence of tearing the fabric of the common law even though the rent is but small ... the Privy Council [has now recognised] ... that the common law may not be the same in Australia as it is in England. ${ }^{55}$

Windeyer was more candid. He was a scholarly judge who was held in particularly high esteem by Dixon (the same could not be said of some of his colleagues). Windeyer was by no means an 'innovator' but was more of a realist than Dixon. ${ }^{56}$ Three years after the decision in Parker, Windeyer delivered a speech at the Thirteenth Dominion Law Conference in New Zealand on the topic of unity in the Common law. ${ }^{57}$ Another invited speaker was Denning. Windeyer's speech is interesting not only for its generous appreciation of judicial creativity at large, ${ }^{58}$ but because it reveals that Windeyer was never of the view that the High Court's proper role involved the consideration of English law at the expense of other helpful precedent. He nevertheless surmised that there was 'misgiving and apprehension' at the idea of the Common law being developed differently in other jurisdictions because

for many people in Britain, Australia and New Zealand ... there is a sentiment born of the past and of the greatness and pride of the past - a feeling of reverence for the law as the law of our peoples, a remembrance of the great days of Empire ... [but] The Australian method is, on final analysis, somewhat different from that of the English Courts. They are inflexibly bound by the decisions of the House of Lords ... From its earliest days the High Court has said that it is its duty to proceed as a national Court of final appeal, for that is the duty that was cast by Imperial Parliament. ... [I]t is desirable to preserve uniformity in our law, [and] decisions of the House of Lords are regarded as of the highest persuasive authority ... But when an English Court has proceeded upon a consideration of English cases only, and seemingly to meet conditions prevailing in England and ignoring what has been said on the matter elsewhere, its decision may have less weight with us. ${ }^{59}$

This passage seems to reflect Dixon's private views as much as Windeyer's. Indeed, it provides a frank expression of the sentiments

${ }^{55}$ D. Menzies, 'Australia and the Judicial Committee of the Privy Council', Australian Law Journal, 42 (1968), 79-87, at 85.

56 A. Mason, 'Foreword', in Debelle (ed.), Victor Windeyer's Legacy, i-xiv, at vi.

57 Windeyer, 'Unity, Disunity and Harmony in the Common Law'.

${ }^{58}$ Ibid., 119.

59 Ibid., 125-6. 
which underscored the decision in Parker. (There should be no surprise at the effortless summation of the mood of the era: Windeyer was a talented legal historian in his own right.) What precedes these observations in the speech, however, is utterly curious. Windeyer knew that these statements were not uncritical of the English courts, so he selfconsciously sought to assure the audience that his remarks should not be construed as an 'unseemly assertion of independence or as a strident expression of Australian nationalism'. ${ }^{60}$ There is a sense of discomfiture in finding that Windeyer then thought it necessary to give the particulars of his own family history ('despite my Swiss name, my family have been British subjects for two hundred and thirty years or thereabouts') to allay any hint of subversiveness. ${ }^{61}$

What might be concluded at this point is that at least several of the judges appeared to have been pulled in two directions in deciding how to proceed in both dealing with the Privy Council and in maintaining a unified Common law. None of this cohort appeared to want to 'take on' the English courts because of their personal fervour for nationalism. The frustrations were evident: the Court felt that its work was not always taken seriously in London; and it had doubts as to the collective capability of the Privy Council. It was no judge's first instinct to deal with these concerns in the most public of ways, that is, through communicating with London via High Court judgments. Instead, alternative, private channels of communication were considered first.

\section{Failed Advocacy}

Dixon, on behalf of the Court, undertook to advocate for change in London via three separate channels - well before he had recourse to the very public declaration in Parker. Despite his efforts, the changes he sought privately did not eventuate: domestic reforms to the appeal process were rejected; and Dixon's remonstrations on the performance of the Privy Council and the 'deliberate innovators' fell on deaf ears.

The first of these efforts was to press domestically for a curtailment of appeals to the Privy Council. Dixon was close friends with Australia's prime minister, Robert Menzies, whose second term in office spanned the years 1949 to 1966 . Menzies had been Dixon's pupil at the bar, and both shared a common bond in their appreciation of the 'civilising influence of

\footnotetext{
60 Ibid., 124.

61 Ibid.
} 
England' in Australian society. ${ }^{62}$ As early as 1952, and well before Dixon's elevation to the chief justiceship, Dixon had expressed concerns privately to Menzies about the performance of the Privy Council namely, its lack of expertise in handling questions of federalism, and its propensity to grant leave to appeal indiscriminately in other matters. Menzies, who would be visiting London the following year, undertook to raise these concerns diplomatically with the lord chancellor (in that period, coincidentally, the lord chancellor was Dixon's friend, Simonds). There is no evidence to suggest that Menzies pressed the case with any zeal, however. In 1954, Dixon had the opportunity to discuss the Privy Council again with a senior barrister, future High Court justice and the prime minister's cousin, Douglas Menzies. Douglas Menzies was convinced the judges did 'no work behind the scenes'; perhaps, he remarked, they considered it poor form to be engaged in any form of preparatory work before hearing Australian appeals. Dixon likely took this as an encouragement. ${ }^{63} \mathrm{He}$ decided to counsel the Prime Minister again to consider his position. This time, rather than press for careful diplomacy in London, Dixon suggested a local solution. The Federal Parliament could take legislative action, as permitted by section 74 of the Constitution, to restrict appeals to the Privy Council - on constitutional matters at the very least. Dixon prepared his own draft of the legislation and arranged for a meeting in which the prime minister could canvas the entirety of the High Court bench at once in order to understand the gravity of the problem. Again, it appeared that the draft was not taken further by the prime minister. Later in life, Menzies explained that he did not object to proposals to restrict appeals on constitutional grounds, but that breaking ties with the Privy Council in Common law cases would be to abandon 'a common inheritance which has much to do ... with true civilisation'. ${ }^{64}$ Perhaps Menzies' commitment to that common inheritance had left him in stasis when Dixon implored him for help.

At around the same time, Dixon decided to take matters into his own hands and press both Simonds (as lord chancellor) and Pearce, then a lord justice of appeal, directly. To Simonds, he wrote to express his concern over the Privy Council's ever-increasing interventions in

\footnotetext{
62 As adopted from a letter from O. Dixon to J. Latham, 15 September 1950, from NLA, MS Acc.09, Box 3, PP7.27.

63 Ayres, Owen Dixon, 245.

64 R. Menzies, Afternoon Light: Some Memories of Men and Events (London, 1967), 324-5.
} 
constitutional affairs, but added that the bench seemed to fail to appreciate unique Australian conditions when hearing appeals more generally. ${ }^{65}$ Dixon hinted of the possibility of a transformation in the Australian political climate following the decision in the Bank Nationalisation case, suggesting that the Labor party might well seek to abolish all Privy Council appeals imminently. This, he presumably hoped, might cause sufficient embarrassment to Simonds as to provoke him to counsel the members of the Privy Council bench to take more care with Australian matters. Dixon wrote that he appreciated that deciding cases for a faraway jurisdiction was an 'Aristotelian' task, but he nevertheless pressed for the quality of judgments to be improved. The Australian reader, he suggested, had a fear that: 'unfamiliarity with Australian conditions, institutions and circumstances and the general background will lead to misunderstandings and misinterpretations, ... [and] mere remoteness and distance will increase the chance of things generally going wrong. ${ }^{66}$ Whether Simonds put Dixon's concerns to his colleagues is not known. Simonds responded some time later, not directly addressing Dixon's concerns but reassuring him that at least one of the upcoming cases to be heard by the Privy Council would likely be dismissed on account of it falling within the inter se restrictions. ${ }^{67}$

Dixon's correspondence with Simonds continued on friendly terms despite this outcome, but it appears that, some time around the point that Brown was decided in the Privy Council, Dixon decided to direct his apprehensions to Pearce in separate correspondence. (Pearce did not sit on the appeal in Brown.) Pearce at least confirmed that he would take up Dixon's concerns with the new lord chancellor. Dixon by this point appeared uncharacteristically intemperate in his expression:

The plain fact is that the dominant consideration with me is to preserve every tie with England, ... [b]ut the difficulties in doing it grow. ... '[F]ederalism' is exotic and you must live under it to understand the problems to which it gives rise. As to care in giving special leave, I suppose it comes down to wisdom of 'legal statesmanship'. [The Privy

${ }^{65}$ Letter from O. Dixon to G. Simonds, [undated] 1954, from NLA, MS Acc.09, Bx 3, PP7.60A.

66 Ibid.

67 Letter from G. Simonds to O. Dixon, 25 April 1956, from NLA, MS Acc.09, Bx 4, PP11.21. 
Council] is not now guided by the principles [in granting leave] which Haldane expounded. ${ }^{68}$

Again, there appears to have been no response that satisfied Dixon. His entreaties to the Privy Council having thus failed, Dixon turned back to the issue of judicial innovation in the general law. In respect of this, there was only one further course of diplomatic action that Dixon considered: to plead with the 'source', Denning, directly. As discussed earlier, the relationship between Dixon and Denning had begun on a firm footing, but as Denning became more vocal about the creative aspects of the judicial function, so did Dixon's cautioning against innovation for its own sake. Dixon decided to use the opportunity given to him, as a recipient of a prize at Yale in 1955, to deliver a lecture containing a call for a return to the time-honoured methods inherent in 'strict and complete legalism'. ${ }^{69}$ He spent much of the lecture on a hypothetical case in which he showed the principles of contract law could be adapted to novel facts without the need for recourse to an amorphous form of estoppel - a topic chosen quite deliberately. He later told colleagues that he had meant to direct those comments to Denning. ${ }^{70}$ Much to Dixon's disbelief, Denning later wrote to tell him that he agreed with everything he had said in the lecture. ${ }^{71}$ Undeterred, Dixon took up the topic again in 1958, this time in person at a visit to Denning's home: he offered criticism of those English judges who treated case law 'otherwise than as a stream of authority. ${ }^{72}$ This did not chasten Denning, who instead affably reaffirmed his confidence in the High Court. Denning and Dixon did not meet again. Denning's hubris (or obliviousness) had proved yet another stumbling block for Dixon.

\section{Denouement}

By the end of 1960, Dixon had grown tired of pursuing private channels of advocacy to voice his, and his colleagues', concerns about the situation in England. He considered his efforts to have been an exercise in futility. His low mood was evident when he wrote to Frankfurter: 'It is needless to

${ }^{68}$ Letter from O. Dixon to E. Pearce, 30 December 1959, from NLA, MS Acc.09, Box 5, PP12.54.

${ }^{69}$ Dixon, 'Concerning Judicial Method'.

${ }^{70}$ Ayres, Owen Dixon, 253.

${ }^{71}$ Ibid.

${ }^{72}$ Ibid., 269. 
tell you, I think, that with respect to both Privy Council appeals and attempts to follow the developments of the law in England my leanings towards purity in the common law have been counterpoised by too much British sentiment. [It is] too much for me .... ${ }^{73}$ The scene was set for a more public voicing of those concerns - and it came with the opportunity presented in the Parker proceedings. When the full circumstances leading up to the Parker decision are examined, it can be seen that Dixon's judgment is, at first glance, hardly cause for jubilant celebration as a landmark in the history of Australian law. The effects of Parker cannot be understated, of course: it placed the High Court, and the lower Australian courts, in a position to widen their points of reference in developing the Common law. It allowed those courts to give precedence to the consideration of local conditions. But the decision did not reflect a bold judicial choice: rather, only necessity. The more edifying options of reaching a London audience had been exhausted. When viewed from the twenty-first century, Parker is sometimes exalted as a stepping-stone to Australian nationhood. But for Dixon, and possibly some of his fellow judges, it is likely to have been regarded as the denouement of a relatively gloomy period in English-Australian legal history.

${ }^{73}$ Letter from O. Dixon to F. Frankfurter, 20 December 1960, from NLA, MS Acc.09, Box 5, PP13.14. 